\title{
ANTIBAKTERI EKSTRAK ETANOL SERBUK KERING Sargassum cristaefolium TERHADAP BAKTERI Escherischia coli DAN Salmonella thyposa
}

\author{
Hartati Kartikaningsih $^{\text {a,b*, }}$, Yuniar Trihartita ${ }^{a}$, Fatih Fuadi ${ }^{b}$ \\ ${ }^{a}$ Laboratorium Keamanan Pangan, Fakultas Perikanan dan Ilmu Kelautan \\ Universitasz Brawijaya, Malang, Indonesia \\ ${ }^{\mathrm{b}}$ Riset Grup Bioseafood, Fakultas Perikanan dan Ilmu Kelautan \\ Universitasz Brawijaya, Malang, Indonesia \\ *Koresponden penulis : hartatikartikaningsih@gmail.com
}

\begin{abstract}
Abstrak
Serbuk kering Sargassum cristaefolium bisa digunakan sebagai campuran pangan dan pakan serta bisa diaplikasikan sebagai serbuk minuman yang mengandung mineral dan bahan aktif triterpenoid. Penelitian ini ditujukan untuk mengetahui aktivitas anti bakteri serbuk kering Sargassum cristaefolium terhadap daya hambat bakteri Escherischia coli dan Salmonella thyposa secara in vitro. Hasil penelitian menunjukkan serbuk kering Sargassum cristaefolium memiliki daya hambat lebih baik pada Salmonella thyposa $(2.3 \mathrm{~mm})$ dibandingkan Escherischia coli $(1.2 \mathrm{~mm})$ walaupun termasuk bakterisidal lemah. Serbuk kering Sargassum cristaefolium menunjukkan positif mengandung alkaloid, flavonoid, triterpenoid dan tannin serta tidak mengandung saponin, memiliki toksisitas rendah (LC50 322 ppm). Uji LCMS menunjukkan satu peak pada retensi 2.16 dengan berat molekul $339.39 \mathrm{~m} / \mathrm{z}$. Struktur bahan aktif antibakteri Sargassum cristaefolium perlu diperjelas dengan menggunakan C-NMR dan H-NMR.
\end{abstract}

Kata kunci: anti bakteri, Escherischia coli, rumput laut coklat, Salmonella thyposa, serbuk kering

\begin{abstract}
Sargassum cristaefolium dried powder can be used as food and fed additives as well as a beverage powder, contained some minerals and terpenoid active ingredients. This study aimed to determine the anti-bacterial activity of Sargassum cristaefolium dried powder on the inhibition of Escherischia coli and Salmonella thyposa bacteria in vitro. The research showed that the dried powder of Sargassum cristaefolium had better inhibition on Salmonella thyposa $(2.3 \mathrm{~mm})$ compared to Escherischia coli $(1.2 \mathrm{~mm})$ although it was classified as weak bactericidal. Sargassum cristaefolium dried powder showed positive testing for alkaloids, flavonoids, terpenoids and tannins and does not contain saponins, had low toxicity (LC50 $322 \mathrm{ppm}$ ). The LCMS test showed a peak at 2.16 retention time with a molecular weight of $339.39 \mathrm{~m} / \mathrm{z}$. The structure of the Sargassum cristaefolium antibacterial active ingredient should be clarified using C-NMR and H-NMR
\end{abstract}

Keywords: antibacterial, Escherischia coli, Phaeophyta dried powder, Salmonella thyposa

\section{PENDAHULUAN}

Rumput laut coklat banyak jenisnya, salah satunya adalah Sargassum cristaefolium. Jenis Sargassum telah diteliti sebagai sumber alginate [1,2,3], bahan pakan udang [4], sumber fukoidan untuk pakan [5], sebagai bahan anti inflamasi [6], anti oksidan dan anti kanker [7] dan bahan bioethanol [8]. Masyarakat Cabbiyya, Talango, Sumenep menggunakan daun Sargassum cristaefolium sebagai bubuk teh. Sargassum cristaefolium direndam dalam air kapur pH 11 selama 6 jam kemudian dikeringkan matahari dan disimpan sebagai bubuk kering teh. Selama ini bubuk kering teh dikenal sebagai sumber antioksidan. Aktivitas antioksidan dan polifenol Sargassum ini telah banyak diteliti. [9] meneliti sejumlah spesies Sargassum terkait dengan aktivitas antioksidannya. [10] meneliti jumlah anti oksidan Sargassum cristaefolium yang tumbuh disekitar perairan Sumenep, Madura. Masih sedikit data terkait aktivitas antibakteri dari bubuk teh Sargassum cristaefolium. Bahan aktif antibacterial 
Sargassum diduga dari kandungan polisakarida sulfat yang terkandung dalam kelompok pikokolid Sargassum [11,12]. Polisakarida sulfat sebagai antibakteri banyak diperoleh dari kelompok alga merah. Sargassum sebagai anti bakteri diteliti oleh [13] dengan bakteri uji beberapa bakteri pathogen penyebab penyakit pada budidaya ikan. Sifat antibakteri Sargassum terhadap bakteri Escherichia coli juga diteliti oleh [14]. Tujuan penelitian ini adalah untuk mendapatkan gambaran seberapa besar aktivitas anti bakteri dari serbuk kering Sargassum cristaefolium terhadap bakteri Escherischia coli dan Salmonella thyposa, dua jenis bakteri Gram negative penyebab sakit perut.

\section{BAHAN DAN METODE}

\section{Pembuatan bubuk kering Sargassum cristaefolium}

Sargassum cristaefolium diperoleh dari perairan Talango, Madura. Sargassum cristaefolium dari perairan laut dicuci dengan air tawar, dimasukkan dalam kantong plastic dengan ditambah sedikit air laut, dimasukkan dalam cool box yang berisi es batu. Sesampai di laboratorium Keamanan Pangan Fakultas Perikanan dan Ilmu Kelautan Universitas Brawijaya Malang, Sargassum cristaefolium dicuci lagi dengan air tawar, direndam dalam air kapur (2:1 b/v pH 11) 6 jam, dicuci lagi dengan air tawar dan dikeringkan dalam oven suhu $50^{\circ} \mathrm{C}$, dihaluskan dengan blender dan disimpan sebagai sampel bubuk kering Sargassum cristaefolium.

Ekstrak kasar bubuk kering Sargassum cristaefolium dilakukan dengan cara maserasi bubuk kering Sargassum cristaefolium dengan ethanol pa (1:5 b/v, 24 jam diaduk dengan magnetic stirrer. Hasil maserasi disentrifuse (Hole Ortegon, $4000 \mathrm{rpm}$ ) selama 15 menit suhu dingin, disaring dengan kertas Whatman. Filtrat yang dihasilkan kemudian dipekatkan menggunakan rotary evaporator (RE2010 1L Xian Yuanxian, China) $40^{\circ} \mathrm{C}, 24$ jam. Filtart digunakan sebagai pengujian antibakteri Escherichia coli dan Salmonella thyposa.

\section{Pengujian anti bakteri bubuk kering Sargassum cristaefolium}

Bakteri Escherichia coli Dan Salmonella thyposa berasal dari koleksi Fakultas Kedokteran Universitas Brawijaya Malang. Kedua bakteri ini ditanam dalam media Muller Hinton Agar (Sigma-Aldrich). Kepadatan bakteri dibuat dengan kepadatan bakteri $10^{8} \mathrm{cfu} / \mathrm{ml}$ dengan cara membuat kurva pertumbuhan pada nutrient broth (Sigma-Aldrich)

dihitung dengan menggunakan haemacitometer. Bakteri uji ditanam pada lempeng agar kepadatan $10^{8} \mathrm{cfu} / \mathrm{mL}$ selama 24 jam $37^{\circ} \mathrm{C}$. Cakram disk direndam dalam larutan ekstrak bubuk kering 10\%, 20\%, 30\% selama 5 menit diletakkan kemedia lempeng agar yang telah terisi bakteri uji. Kontrol positif menggunakan streptomisin 10.000 ppm. Kontrol negatife dengan menggunakan DMSO 5\%. Semua perlakuan diulang 3 kali. Aktivitas bakteri diukur dengan mengukur zona zernih disekitar kertas disk. Rancangan penelitian yang digunakan adalah Rancangan Acak Lengkap (RAL) dengan 3 perlakuan. yakni menggunakan ekstrak teh rumput laut coklat Sargassum cristaefolium (10\%, 20\%, $30 \%)(\mathrm{v} / \mathrm{v})$ dan 1 kontrol pembanding. Masing-masing perlakuan diuji daya hambatnya pada bakteri Escherichia coli dan Salmonella thyposa secara duplo.

\section{Pengujian bahan aktif bubuk kering Sargassum cristaefolium dengan LCMS}

Pengujian LC-MS dilakukan di Laboratorium Pusat Pengujian Kimia LIPI Serpong Tangerang Selatan menggunakan LC-MS Biospectrometry (merk LC Hitachi L6200) dengan volume injeksi sampel $20 \mathrm{ul}$, flow rate $0.5 \mathrm{ml} / \mathrm{min}$ dan menggunakan eluent methanol serta dengan kolom C18 (RP 18) Phenomenex, panjang kolom $150 \mathrm{~nm}$, diameter kolom $2 \mathrm{~mm}$ dan ukuran partikel 5 $\mu \mathrm{m}$.

\section{Pengujian bahan aktif serbuk kering Sargassum cristaefolium dengan GCMS}

Pengujian GCMS dilakukan di Laboratorium Kimia Fakultas MIPA Universitas Brawijaya dengan merek GCMS QP2010, suhu kolom $100^{\circ} \mathrm{C}$, suhu injeksi sampel $290^{\circ} \mathrm{C}$, suhu sumber ion $290^{\circ} \mathrm{C}$, suhu interface $250^{\circ} \mathrm{C}$, tekanan $100 \mathrm{kPa}$, total aliran sampel $50 \mathrm{~mL} /$ menit, aliran sampel dalam 
kolom $1.33 \mathrm{ml} / \mathrm{menit}$, dimulai pada $\mathrm{m} / \mathrm{z} 40,00$ dan diakhiri m/z 350,00.

\section{Uji fitokimia}

Untuk mengetahui keberadaan komponen bioaktif yang terdapat dalam rumput laut coklat Sargassum cristaefolium merupakan tujuan dari pengujian fitokimia. Terdapat pengujian lain yang dilakukan untuk pengujian fitokimia yaitu uji alkaloid, steroid/triterpenoid, flavonoid, saponin, dan tannin. Metode pengujian berdasarkan [15] yang meliputi:

\section{Pengujian alkaloid:}

Identifikasi alkaloid dilakukan dengan menambahkan $2 \mathrm{~mL} \mathrm{HCl} 2 \mathrm{~N}$ pada $2 \mathrm{~mL}$ ekstrak Sargassum cristaefolium, kemudian ditambahkan beberapa tetes pengujian Dragendorff, pereaksi Meyer, dan pereaksi Wagner. Adanya alkaloid akan ditunjukkan terbentuknya endapan putih kekuningan dengan pereaksi Meyer, endapan coklat dengan pereaksi Wagner dan endapan merahmerah jingga pada pereaksi Dragendorff

\section{Pengujian flavonoid:}

$2 \mathrm{~mL}$ ekstrak Sargassum cristaefolium ditambahkan $1 \mathrm{~mL} 2 \mathrm{~N} \mathrm{NaOH}$. Terbentuknya warna kuning menunjukkan ekstrak positif mengandung flavonoid.

\section{Pengujian triterpenoid/steroid:}

Identifikasi triterpenoid/Steroid dilakukan dengan melarutkan $4 \mathrm{~g}$ sampel dalam $25 \mathrm{~mL}$ etanol kemudian disaring. $0.5 \mathrm{~mL}$ ekstrak Sargassum cristaefolium ditambahkan $2 \mathrm{ml}$ kloroform dan aquades $(1: 1 \mathrm{v} / \mathrm{v})$, distirer. Lapisan yang terbentuk dikeringkan pada hot plate dan tambahkan pereaksi Liebermanburchard sebanyak 1 tetes. Warna merah menunjukkan positif mengandung senyawa triterpenoid dan warna biru - hijau untuk senyawa steroid

\section{Pengujian tannin:}

Identifikasi senyawa tannin dilakukan dengan menambahkan $1 \mathrm{~mL} \mathrm{FeCl3} \mathrm{5 \%} \mathrm{kedalam} 1 \mathrm{~mL}$ ekstrak Sargassum cristaefolium. Terbentuknya warna biru gelap atau hijau kehitaman mengindikasikan adanya senyawa tannin.

\section{Pengujian saponin (uji busa):}

$2 \mathrm{ml}$ ekstrak Sargassum cristaefolium ditambahkan $2 \mathrm{~mL}$ air destilata dicokok pada tabung silinder selama 15 menit. Terbentuknya $1 \mathrm{~cm}$ lapisan busa mengidentifikasikan senayawa mengandung saponin.

\section{Uji Toksisitas}

Pengujian toksisitas ekstrak Sargassum cristaefolium in vitro dengan menggunakan hewan uji Artemia salina Leach yang dihitung dengan menggunakan analisis probit [16]. Telur Artemia salina Leach sebanyak $5 \mathrm{~g}$ direndam dalam air tawar selama 15-30 menit, kemudian dipindah dalam rendaman air lau tdengan suhu $\pm 25-30^{\circ} \mathrm{C}$ dan $\mathrm{pH} \pm 7-8$. Nauplii akan menetas dalam waktu 18-24 jam. Ekstrak Sargasssum cristaefolium dengan konsentrasi $1000 \mathrm{ppm}, 500 \mathrm{ppm}, 250 \mathrm{ppm}$, $125 \mathrm{ppm}, 62,5 \mathrm{ppm}$ dan 0 ppm dimasukkan bejana uji. Setiap bejana uji diberikan 30 ekor nauplii Artemia salina Leach. LC 50 dihitung 124 jam.

\section{HASIL DAN PEMBAHASAN}

Zona hambat menunjukan pada tiap perbedaan konsentrasi dan sampel menunjukan perbedaan. Pada control menunjukan zona hambat Salmonela thyposa lebih besar dari Escherischia.coli sebesar 13,73 mmdan 12,73 mm. Pada konsentrasi ekstrak Sargassum cristaefolium 10\% menunjukan zona hambat Salmonella thyposa lebih besar sebesar 3,13 $\mathrm{mm}$ dan Escherichia coli sebesar 2,41 mm.Hal yang sama ditunjukkan pada daya hambat ekstrak Sargassum cristaefolium 20\% dan 30\%, yakni $3,76 \mathrm{~mm}$ dan $4,48 \mathrm{~mm}$ pada Salmonella thyposa serta $3,34 \mathrm{~mm}$ dan $3.87 \mathrm{~mm}$ pada Escherichia coli. Terjadi perbedaan yang cukup signifikan pada konsentrasi $30 \%$. Pada konsentrasi $30 \%$ menjadi daya hambat yang paling baik, namun aktivitas bakteri tersebut jauh lebih rendah dibandingkan dengan control Streptomycin. (Gambar 1) 


\section{Uji Daya Hambat}

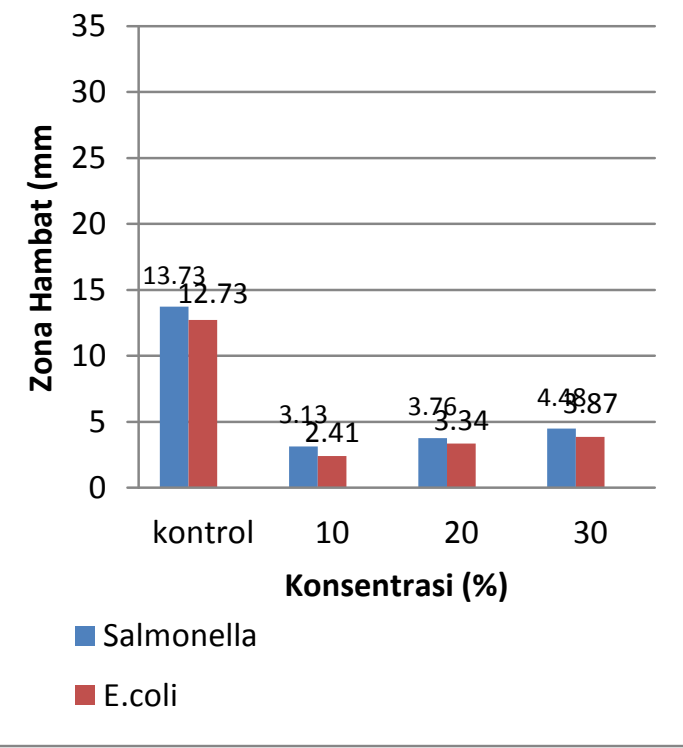

Gambar 1. Hasil uji daya hambat bubuk kering Sargassum cristaefolium

Bila dikaitkan dengan nilai LC50 (Tabel 1), bubuk kering Sargassum cristaefolium memiliki toksisitas sedang dengan hewan uji Artemia salina. Sifat anti bakteri kelompok Sargassum terkait dengan kandungan sulfat pada pikokoloidnya. Sargassum cristaefolium sering disebut dengan sampah laut, belum ada industri yang memanfaatkannya disebabkan kadar pikokoloid yang kadarnya lebih rendah dibandingkan jenis alga merah. Namun, bila digunakan sebagai bahan pakan dan pangan, bubuk kering Sargassum cristaefolium masih tergolong aman untuk digunakan dan memiliki aktivitas anti bakteri yang rendah terhadap Escherischia coli dan Salmonella thyposa.

Dari kedua jenis bakteri ini, anti bakteri Sargassum cristaefolium lebih baik untuk menghambat bakteri Salmonella thyposa dibandingkan bakteri Escherichia coli. Ekstrak rumput laut Phaeophyta lebih baik sebagai antibakteri gram positif seperti Staphylococcus aureus dibandingkan bakteri gram negative $[17,18]$. Sifat antibakteri ini terkait dengan mucopolisakarida yang ada di dalam Pheophyta 19; 1]. Escherichia coli dan Salmonella thyposa, keduanya termasuk bakteri Gram negative yang memiliki antigen
O sehingga mukopolisakarida yang ada dalam rumput laut ini kurang dapat menghambat pertumbuhannya.

Tabel 1.Hasil uji LC50 Sargassum cristaefolium $\backslash$

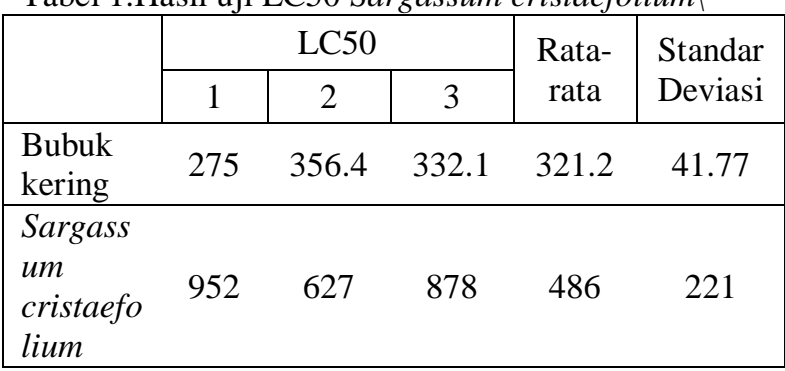

Pengujian anti bakteri beberapa rumput laut dan kandungan fitokimianya juga dilakukan oleh [18]. Sifat antibakteri phaeophyta terkait dengan kandungan fitokimianya [20]. Selain kandungan mucopolisakarida dari phaeophyta, bahan antibakteri yang lain adalah kelompok polifenol.[21], pigmen [22], quercetin dan pigmen [23]. Hasil uji bahan aktif yang terdapat pada bubuk kering Sargassum cristaefolium terlihat pada Tabel 2. Kondisi segar, kering ataupun bubuk kering (yang telah dilakukan proses perendaman kapur) tetap menunjukkan senyawa triterpenoid dengan kadar yang paling banyak dibandingkan komponen lainnya.

Tabel 2. Hasil uji fitokimia bubuk kering Sargassum cristaefolium

\begin{tabular}{lccc}
\hline Parameter & Segar & Kering & $\begin{array}{c}\text { Bubuk } \\
\text { Kering }\end{array}$ \\
\hline Alkaloid & ++ & + & + \\
\hline Flavonoid & ++ & + & + \\
\hline $\begin{array}{l}\text { Triterpenoid/ } \\
\text { Steroid }\end{array}$ & ++ & ++ & ++ \\
\hline Tanin & & & \\
\hline Saponin & + & + & + \\
\hline
\end{tabular}

Antibakteri kelompok alga diduga adanya kandungan fenolik dan flavonoidnya $[24,15]$. Senyawa flavonoid adalah senyawa yang mengandung $\mathrm{C}_{15}$ terdiri dari dua inti fenolat yang dihubungkan dengan tiga satuan karbon. Banyak tanaman obat herbal mengandung senyawa flavonoid kompleks yang tidak berwarna dan bila dihidrolisis dengan asam akan kembali menjadi antosianidin dan kathekin. Flavonoid merupakan kelompok senyawa fenolik terbesar yang terdapat di alam. Berdasarkan 
kerangka karbon strukturnya senyawa flavonoid dibagi menjadi 6 sub kelompok utama yaitu flavon, flavonol, flavanon, flavanol, isoflavon, dan antosianidin. Hasil penelitian yang telah dilakukan menunjukkan hasil positif adanya senyawa flavonoid pada alga coklat Sargassum cristaefolium.

Triterpenoid merupakan senyawa berkerangka karbon yang tersusun atas enam unit isoprena dan secara biosintesis diturunkan dari skualen. hidrokarbon C30 asiklik Triterpena berasa pahit. Secara alami, triterpena dalam tumbuhan mempunyai fungsi sebagai pelindung terhadap serangan serangga dan mikroba. Salah satu golongan triterpenoid adalah steroid, yang digunakan sebagai bahan obat herbal.. Hasil uji fitokimia pada alga coklat Sargassum cristaefolium menunjukkan hasil yang positif terhadap adanya senyawa steroid/triterpenoid, alkaloid, flavonoid dan tannin.

Hasil GCMS bubuk kering Sargassum cristaefolium mengandung 10 komponen bahan aktif seperti yang terlihat pada Tabel 3 . Dominasi bahan aktifnya adalah kelompok dimethyl benzene $(49.37 \%)$, amida $(11.91 \%$, asam $(8.23 \%)$ dan aldehid $(7.96 \%)$. Stuktur benzene merupakan tulang punggung struktur fitokimia tanaman, termasuk juga alga. [25] memperlihatkan hasil spekstrum ekstrak methanol Acanthopora specifera yang memiliki gugus fenol, alkane, alkena, asam karboksilat, aromatic, alkohol, benzene, komponen nitro dan bromo alkane. [26] menyebutkan komponen anti microbial dari algae adalah deprival chlorellin, asam akrilik, terpen, alifatik terhalogenasi, fenol, komponen heterosiklik yang mengnadung sulfur. Terkait dengan hasil LCMS, bubuk kering Sargassum cristaefolium terlihat satu puncak pada retensi 2.2 dengan berat molekul $339.29 \mathrm{~m} / \mathrm{z}$ (Gambar 2 dan 3). Gambar 3 memperlihatkan fargmentasi yang ditandai dengan beberapa puncak ion. Berat molekul senyawa sebesar 339,29 m/z. Berdasarkan penelusuran database spektra massa melalui internet, senyawa dengan berat molekul $339,29 \mathrm{~m} / \mathrm{z}$ diduga adalah senyawa 3-Acetoxy4'-methoxy-6,8-Dimethylflavone dengan berat molekulnya $338,11542 \mathrm{~m} / \mathrm{z}$ dengan rumus molekulnya $\mathrm{C}_{20} \mathrm{H}_{18} \mathrm{O}_{5}$. Senyawa ini merupakan golongan flavonoid.
Tabel 3. Hasil komponen Sargassum cristaefolium dengan GCMS

\begin{tabular}{|c|c|c|c|}
\hline No & Dugaan senyawa & $\begin{array}{l}\text { Rumus } \\
\text { molekul }\end{array}$ & $\%$ \\
\hline 1 & $\begin{array}{l}\text { 5,5'-Dicarboxy-3'-(2- } \\
\text { Chloroethyl)-4-(2- } \\
\text { Acetoxyethyl)-3,4'- } \\
\text { Dimethylpyrromethane }\end{array}$ & $: \mathrm{C}_{19} \mathrm{H}_{23} \mathrm{C}_{1} \mathrm{~N}_{2} \mathrm{O}_{6}$ & 4.29 \\
\hline 2 & $\begin{array}{l}\text { Spiro[2.5]Oct-6-eneE-4- } \\
\text { Acetaldehyde }\end{array}$ & $\mathrm{C}_{10} \mathrm{H}_{14 \mathrm{O}}$ & 7.96 \\
\hline 3 & 1,2-Dimethylbenzene & $\mathrm{C}_{8} \mathrm{H}_{10}$ & 49.37 \\
\hline 4 & $\begin{array}{l}\text { 2-Hydroxy-3-(2- } \\
\text { Methoxyethyl)-3- } \\
\text { Buteamide }\end{array}$ & $\mathrm{C}_{23} \mathrm{H}_{28} \mathrm{~N}_{2} \mathrm{O}_{4}$ & 11.91 \\
\hline 5 & Ethyl 3,3A-Cis-2-Benzyl & $\mathrm{C}_{28} \mathrm{H}_{27} \mathrm{~N}_{3} \mathrm{O}_{4}$ & 2.52 \\
\hline 6 & Ethaneperoxoic Acid & $\mathrm{C}_{11} \mathrm{H}_{11} \mathrm{NO}_{3}$ & 8.23 \\
\hline 7 & $\begin{array}{l}\text { Benzoyl-1H-Naphth[2,3- } \\
\text { Djimidazole-6,7- } \\
\text { Dicarboxylic Anhydride }\end{array}$ & $\mathrm{C}_{20} \mathrm{H}_{10} \mathrm{~N}_{2} \mathrm{O}_{4}$ & 6.55 \\
\hline 8 & $\begin{array}{l}\text { 7-Hydroxy-7-Phenyl-3,9- } \\
\text { Diisopropyl-2,10- } \\
\text { Dioxadispiro[3.3.3.1]Dode } \\
\text { can-1,11-Dione }\end{array}$ & $\mathrm{C}_{22} \mathrm{H}_{28} \mathrm{O}_{5}$ & 1.78 \\
\hline 9 & $\begin{array}{l}\text { 7- } \\
\text { Oxabicyclo[4.1.0]Heptane } \\
\text {, 3-Buten-2-One }\end{array}$ & $\mathrm{C}_{13} \mathrm{H}_{20} \mathrm{O}_{2}$ & 1.92 \\
\hline 10 & Octyl Phenyl Ketone & $\mathrm{C}_{15} \mathrm{H}_{22} \mathrm{O}$ & 5.47 \\
\hline
\end{tabular}

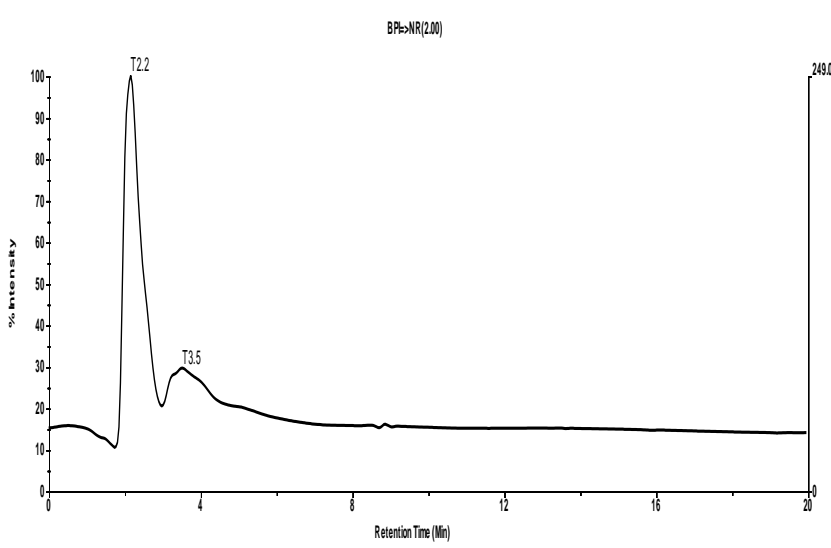

Gambar 2. Hasil uji LCMS bubuk Sargassum cristaefolium 


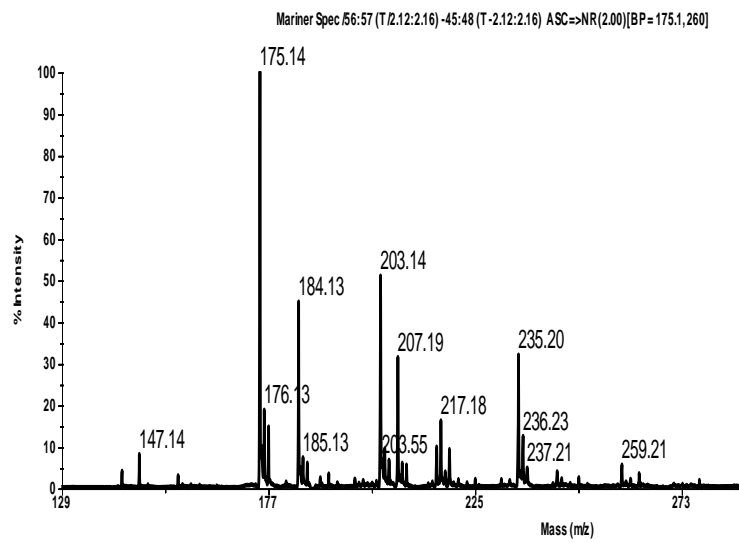

Gambar 3 Berat molekul senyawa Sargassum cristaefolium

\section{KESIMPULAN}

Bubuk kering Sargassum cristaefolium memiliki aktivitas anti bakteri yang rendah terhadap bakteri Escherischia coli dan Salmonella thyposa. Bahan anti bakteri diduga berasal dari flavonoid dengan berat molekul $339.29 \mathrm{~m} / \mathrm{z}$, namun jenis bahan aktif ini stuktur kimianya perlu uji lanjut dengan HNMR dan CNMR

\section{UCAPAN TERIMAKASIH}

Ucapan terimakasih kepada Rektor Universitas Brawijaya dan Dekan Fakultas Perikanan dan Ilmu Kelautan atas dana penelitian DIPA tahun 2019 dengan nomor SK Dekan FPIK UB no 54 tahun 2019. Ucapan terima kasih kepada Fuad dan Tita atas bantuannya dalam pengerjaan laboratorium

\section{DAFTAR PUSTAKA}

[1] Zubia, M., Payri, C. and Deslandes, E. "Alginate, mannitol, phenolic compounds and biological activities of two range-extending brown algae, Sargassum mangarevense and Turbinaria ornata (Phaeophyta: Fucales), from Tahiti (French Polynesia)". J. Appl.Phycol vol 20, no 6, hal.1033-1043 .Journal of Applied Phycology,20(6), pp.1033-1043. 2008

[2] Salosso, Y. and Jasmanindar, Y. "Diversity of brown macroalgae in Kupang Bay waters and alginate content potential and its phytochemistry". Aquacult Aquarium Conserv Legislation vol 11 no 3 hal 598605. 2018

[3] Sugiono, S., Masruri, M., Estiasih, T. and Widjarnako, S.B. "Structural and Rheological Characteristics of Alginate from Sargassum cristaefolium Extracted by Twin Screw Extruder". J.Aquat Food Prod Technol Journal of Aquatic Food ${ }^{32}$ Product Technology, pp.1-16. October 2, 2019

[4] Sudaryono, A., Haditomo, A.H. and Isnansetyo, A.. "Evaluation of dietary supplementation of aqueous extract of brown algae Sargassum cristaefolium on growth performance and feed utilization of juvenile white shrimp Litopenaeus vannamei". AACL Bioflux, vol 8 no 2 2015

[5] Isnansetyo, A., Fikriyah, A. and Kasanah, N. "Non-specific immune potentiating activity of fucoidan from a tropical brown algae (Phaeophyceae), Sargassum cristaefolium in tilapia (Oreochromis niloticus)" Aquac Int vol 24 no 2 hal 465-477. .2016

[6] Wu, G.J., Shiu, S.M., Hsieh, M.C. and Tsai, G.J.”Anti-inflammatory activity of a sulfated polysaccharide from the brown alga Sargassum cristaefolium." Food Hydrocolloloids vol 53 hal 16-23. 2016

[7] Wang, C.Y., Wu, T.C., Hsieh, S.L., Tsai, Y.H., Yeh, C.W. and Huang, C.Y. "Antioxidant activity and growth inhibition of human colon cancer cells by crude and purified fucoidan preparations extracted from Sargassum cristaefolium”. J Food Drug Anal.vol 23 no 4 hal 766-777.2015

[8] Borines, M.G., De Leon, R.L. and McHenry, M.P. "Bioethanol production from farming non-food macroalgae in Pacific island nations: Chemical constituents, bioethanol yields, and prospective species in the Philippines." Renewable \& Suatainable Energy Rev.vol 15 no 9 hal 4432-4435. 2011 
[9] Balanquit, B.J.R. and Fuentes, R.G. "Preliminary Phycochemical Screening and Antioxidant Activity of Some Brown Algae Sargassum Species From Lawaan, Eastern Samar".J. Nat Stud vol 14 no 1 hal 12-21. 2015

[10] Lailiyah, A., Adi, T.K. and Yusnawan, E. "Kapasitas Antioksidan dan Kandungan Total Senyawa Fenolik Ekstrak Kasar Alga Coklat Sargassum cristaefolium dari Pantai Sumenep Madura". Alchemy hal 18-30. 2014

[11] Sanjeewa, K.A., Kang, N., Ahn, G., Jee, Y., Kim, Y.T. and Jeon, Y.J. "Bioactive potentials of sulfated polysaccharides isolated from brown seaweed Sargassum spp in related to human health applications: a review". Food Hydrocolloids vol 81 hal 200-208. 2018

[12] Nazia Auckloo, B. and Wu, B., 2016. "Structure, biological properties and applications of marine-derived polysaccharides". Curr Org Chem vol 20 no 19 hal 2002-2012. 2016

[13] Bolaños, J.M., Baleta, F.N. and Cairel, J.D. "Antimicrobial Properties of Sargassum spp.(Phaeophyceae) against Selected Aquaculture pathogens". Int. J. Curr. Microbiol. App. Sci, 6(2), vol 6 no 2 hal 1024-1037.2017

[14] Triastinurmiatiningsih, T. and Haryani, T.S. "Potensi Rumput Laut Di Pantai Bayah, Kabupaten Lebak, Banten Sebagai Antibakteri Escherichia coli". J. Mat Sains dan Teknol.vol 9 no 1 hal 3743. 2017

[15] Deyab, M. D., Elkatony, T., \& Ward, F. "Qualitative and quantitative analysis of phytochemical studies on brown Seaweed, Dictyota dichotoma". Int. J.Eng Dev Res vol 2 hal 674-678. 2016

[16] Ayesha, H., Sultana, V., Ara, J., \& Ehteshamul-Haque, S. "In vitro cytotoxicity of seaweeds from Karachi coast on brine shrimp". Pak J
Bot, volume 42 no 5 hal $3555-3560$ 42(5), 3555-3560.2010

[17]Eom, S. H., Kang, M. S., \& Kim, Y. M. "Antibacterial activity of the phaeophyta Ecklonia stolonifera on methicillinresistant Staphylococcus aureus".Fish \& Aquat Sci vol 11 no 1 hal 1-6 .2008

[18] Mansuya, P., Aruna, P., Sridhar, S., Kumar, J. S., \& Babu, S. "Antibacterial activity and qualitative phytochemical analysis of selected seaweeds from Gulf of Mannar region". J. Exp Sci vol 1 no 8 hal 23-26.November 62010

[19] Criado, M. T., \& Ferreiros, C. M. "Toxicity of an algal mucopolysaccharide for Escherichia coli and Neisseria meningitidis strains". Rev Esp.Physiol.vol 40 no 2 hal 227-230. 1984

[20] Kumar, I. N., Barot, M., \& Kumar, R. "Phytochemical analysis and antifungal activity of selected seaweeds from". $J$ Coast Life Med, vol 2 no 7 hal 535-540. 2014

[21] Vijayabaskar, P., \& Shiyamala, V. "Antibacterial activities of brown marine algae (Sargassum wightii and Turbinaria ornata) from the Gulf of Mannar Biosphere Reserve". Adv in Biol. Res vol 5 no 2 hal 99-102 ..2011

[22] Bhagavathy, S., Sumathi, P., \& Bell, I. J. S. "Green algae Chlorococcum humicola-a new source of bioactive compounds with antimicrobial activity". Asian Pasific J. Trop.Biomed vol 1 no 1 hal 1-.7. 2011

[23] Abdo, S. M., Hetta, M. H., Samhan, F. A., Din, R. E., \& Ali, G. H. "Phytochemical and antibacterial study of five freshwater algal species". Asian J. Plant Sci vol 11 no 3 hal 109. 2012

[24] Akremi, N., Cappoen, D., Anthonissen, R., Verschaeve, L., \& Bouraoui, A. "Phytochemical and in vitro antimicrobial and genotoxic activity in the brown algae Dictyopteris 
membranacea". South African J Bot. vol 108 hal 308-314. 2017

[25] Omar, H., Al-Judaibiand, A., \& ElGendy, A. "Antimicrobial, Antioxidant, Anticancer Activity and Phytochemical Analysis of the Red Alga, Laurencia papillosa". Int J.Pharm vol 14 no 4 hal 572-583 . 2018
[26] Ibtissam, C., Hassane, R., Jose, M., Francisco, D. S. J., Antonio, G. V. J., Hassan, B., \& Mohamed, K. "Screening of antibacterial activity in marine green and brown macroalgae from the coast of Morocco". African J Biotechnol vol 8 no 7 hal 99-106, 2009 